\title{
Endoplasmic reticulum stress response is involved in nonsteroidal anti-inflammatory drug-induced apoptosis
}

\author{
S Tsutsumi ${ }^{1}$, T Gotoh ${ }^{2}$, W Tomisato ${ }^{1}$, S Mima ${ }^{1}$, T Hoshino ${ }^{1}$, \\ H-J Hwang ${ }^{1}$, H Takenaka ${ }^{1}$, T Tsuchiya ${ }^{1}$, M Mori ${ }^{2}$ and \\ T Mizushima ${ }^{\star, 1}$ \\ 1 Faculty of Pharmaceutical Sciences, Okayama University, Okayama, Japan \\ 2 Department of Molecular Genetics, Kumamoto University School of Medicine, \\ Kumamoto, Japan \\ * Corresponding author: T Mizushima, Faculty of Pharmaceutical Sciences, \\ Okayama University, 1-1-1, Tsushima-naka, Okayama 700-8530, Japan \\ E-mail: mizushima@pharm.okayama-u.ac.jp
}

Received 19.9.03; revised 05.2.04; accepted 06.2.04; published online 07.5.04 Edited by $\mathrm{H}$ Ichijo

\begin{abstract}
Apoptosis induced by nonsteroidal anti-inflammatory drugs (NSAIDs) is involved not only in the production of NSAIDinduced gastric lesions but also in the antitumor activity of these drugs. The endoplasmic reticulum (ER) stress response is a cellular mechanism that aids in protecting the ER against ER stressors and is involved in ER stressor-induced apoptosis. Here, we examine the relationship between this response and NSAID-induced apoptosis in cultured guineapig gastric mucosal cells. Exposure of cells to indomethacin, a commonly used NSAID, induced GRP78 as well as CHOP, a transcription factor involved in apoptosis. Three factors that positively regulate CHOP expression (ATF6, ATF4 and XBP-1) were activated and/or induced by indomethacin. NSAIDs other than indomethacin (diclofenac, ibuprofen and celecoxib) also induced CHOP. Monitoring of the transcriptional activities of ATF6 and CHOP by luciferase assay revealed that both were stimulated in the presence of indomethacin. Furthermore, indomethacin-induced apoptosis was suppressed in cultured guinea-pig gastric mucosal cells by expression of the dominant-negative form of CHOP, or in peritoneal macrophages from $\mathrm{CHOP}$-deficient mice. These results suggest that ER stress response-related proteins, particularly CHOP, are involved in NSAID-induced apoptosis.
\end{abstract}

Cell Death and Differentiation (2004) 11, 1009-1016.

doi:10.1038/sj.cdd. 4401436

Published online 7 May 2004

Keywords: NSAIDs; apoptosis; endoplasmic reticulum; CHOP; gastric mucosal cells

Abbreviations: ASK1, apoptosis signal-regulating kinase 1; ATF, activating transcription factor; CHOP, C/EBP homologous transcription factor; COX, cyclooxygenase; EGFP, enhanced green fluorescent protein; ER, endoplasmic reticulum; ERSE, ER stress response element; FBS, fetal bovine serum; GRP, glucose-regulated protein; IRE1, protein-kinase and site-specific endoribonuclease; JNK, c-jun $\mathrm{NH}_{2}$-terminal kinase; MTT, 3-(4, 5dimethyl-thiazol-2-yl)-2, 5-diphenyl tetrazolium bromide; NSAIDs, nonsteroidal anti-inflammatory drugs; PEK, pancreatic elF2 kinase; PERK, protein kinase R-like ER kinase; PG, prostaglandin; TRAF2, tumor necrosis factor receptor-associated factor; UPR, unfolded protein response; XBP-1, X box binding protein

\section{Introduction}

Nonsteroidal anti-inflammatory drugs (NSAIDs) are one of the most frequently used classes of medicines in the world and account for nearly $5 \%$ of all prescribed medications. ${ }^{1}$ NSAIDs have great efficacy in the treatment of pain, inflammation and fever on account of their inhibition of cyclooxygenase (COX) activity. COX is essential for the synthesis of prostaglandins (PGs), which have a strong involvement in the induction of inflammation. Recently, clinically beneficial properties of NSAIDs other than anti-inflammation have been revealed. Epidemiological studies revealed that prolonged use of aspirin or other NSAIDs reduces the risk of cancer and Alzheimer's disease. $^{2-4}$ These activities of NSAIDs were confirmed by a number of in vivo and in vitro experiments. Since these activities of NSAIDs cannot be fully explained by the COXinhibition, ${ }^{5,6} \mathrm{COX}$-independent actions of NSAIDs are necessary to be identified.

NSAID administration is associated with gastrointestinal complications, such as gastric ulcers. ${ }^{7}$ In the United States, about 16500 people die per year as a result of NSAIDassociated gastrointestinal complications. ${ }^{8}$ We recently suggested that direct cytotoxic effects of NSAIDs (such as induction of apoptosis), that is, COX-independent are involved in NSAID-induced gastric lesions in vivo. ${ }^{9}$ Furthermore, in addition to inhibition of angiogenesis and cell growth by NSAIDs, induction of apoptosis by NSAIDs is also involved in their antitumor activities. ${ }^{6}$ Therefore, elucidation of the mechanism of NSAID-induced apoptosis is important to understand the mechanism of both NSAID-induced gastric lesions and their antitumor activities. We previously reported that activation of caspases (caspase-3, -8 and -9) is accompanied with induction of apoptosis by NSAIDs. ${ }^{10}$ However, the upstream pathways of apoptosis induced by NSAIDs remain unknown.

Accumulation of unfolded protein in the endoplasmic reticulum (ER) induces the ER stress response, otherwise known as the unfolded protein response (UPR). In the mammalian ER stress response, three types of ER transmembrane proteins are important: protein-kinase and sitespecific endoribonuclease (IRE1), protein kinase R-like ER kinase/pancreatic elF2 kinase (PERK/PEK) and activating transcription factor 6 (ATF6). ${ }^{11-13}$ The mammalian ER stress response can be separated into two phases, adaptation and 
apoptosis. Cells initially adapt to the accumulation of unfolded proteins by inducing ER-resident stress proteins (molecular chaperons) such as glucose-regulated protein (GRP) 78 and GRP94. ${ }^{14-17}$ These proteins refold the unfolded proteins in an attempt to maintain homeostasis in the ER. However, if this adaptation does not prove sufficient, the apoptotic response is initiated, by both ATF6- and ATF4-dependent activation of $\mathrm{C} /$ EBP homologous transcription factor (CHOP).$^{18}$ In this study, we revealed that NSAIDs induce ER stress response. We found that indomethacin induces both GRP78 and CHOP. It also causes activation of ATF6, ATF 4 and $X$ box binding protein (XBP-1). Experiment using the dominant-negative form of $\mathrm{CHOP}$ and cells from CHOP-deficient mice implicated that the activation of CHOP is involved in NSAID-induced apoptosis.

\section{Results}

\section{Induction of GRP78 and CHOP by indomethacin associated with apoptosis}

We have previously reported that long-term (16h) treatment of primary cultures of guinea-pig gastric mucosal cells with NSAIDs (1 mM for indomethacin) induces apoptosis. ${ }^{10}$ In order to reveal the pathway underlying this apoptosis, we used DNA microarray techniques to search for genes whose expression is stimulated by indomethacin under these apoptotic conditions, successfully identifying GRP78 as one such gene (S Mima et al., unpublished results). In the present study, we first confirmed the indomethacin-dependent induction of GRP78 in gastric mucosal cells. Figure 1 shows the time-course and dose-response of apoptosis induced by indomethacin. A decrease in cell viability and apoptotic DNA fragmentation were observed when cells were treated with 0.5-1 mM indomethacin for 4-16h (Figure 1), this being consistent with our previously reported results. ${ }^{10}$ We also confirmed the induction of apoptosis by showing the chromatin condensation and caspase- 3 activation under the conditions (data not shown). Furthermore, we showed that almost all cells were not stained with propidium iodide, ${ }^{10}$ showing that necrosis was not induced under the conditions (less than $1 \mathrm{mM}$ ) (data not shown). In subsequent experiments, we treated cells with $1 \mathrm{mM}$ indomethacin for $16 \mathrm{~h}$ in order to examine the mechanism underlying this apoptosis.

The effect of indomethacin on the expression of GRP78 was examined by immunoblotting analysis (Figure 2). GRP78 was present in nontreated control cells and increased in response to treatment with thapsigargin (an inhibitor of sarco $\mathrm{ER} \mathrm{Ca}^{2+}$ ATPase and a representative inducer of the ER stress response), as previously described. ${ }^{19}$ Indomethacin slightly but significantly increased the amount of GRP78 (Figure 2). We also examined the effect of indomethacin on the expression of another ER stress response-related protein, $\mathrm{CHOP}$, a transcription factor, which induces apoptosis. CHOP was not present in nontreated cells, but was induced by thapsigargin, this being consistent with previously reported results. ${ }^{19}$ Indomethacin clearly induced $\mathrm{CHOP}$, and to a greater extent than thapsigargin (Figure 2).

We also examined the effect of indomethacin on the expression of GRP78 and CHOP mRNA by Northern blotting analysis (Figure 3). Similar to thapsigargin, indomethacin

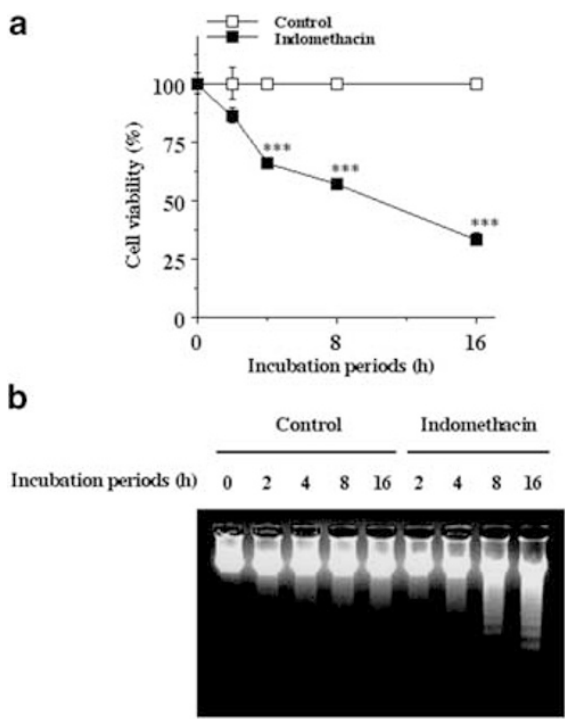

c

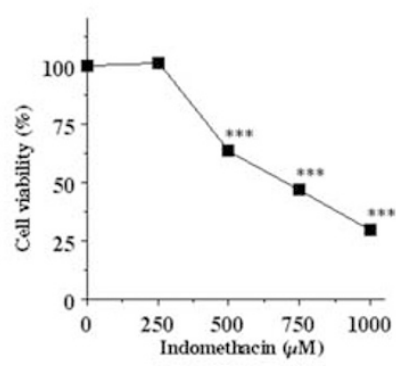

d

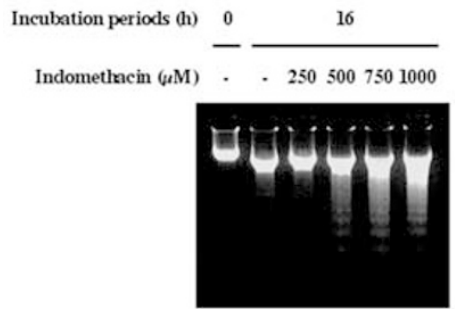

Figure 1 Apoptosis induced by indomethacin. Cultured gastric mucosal cells were incubated with $1 \mathrm{mM}(\mathbf{a}, \mathbf{b})$ or the indicated concentrations $(\mathbf{c}, \mathbf{d})$ of indomethacin for the indicated periods $(\mathbf{a}, \mathbf{b})$ or $16 \mathrm{~h}(\mathbf{c}, \mathbf{d})$. Cell viability was determined by the MTT method. Values are expressed as mean + S.E.M. $(n=4) .{ }^{* * *} P<0.001(\mathbf{a}, \mathbf{c})$. Chromosomal DNA was extracted and analyzed by $2 \%$ agarose gel electrophoresis $(\mathbf{b}, \mathbf{d})$

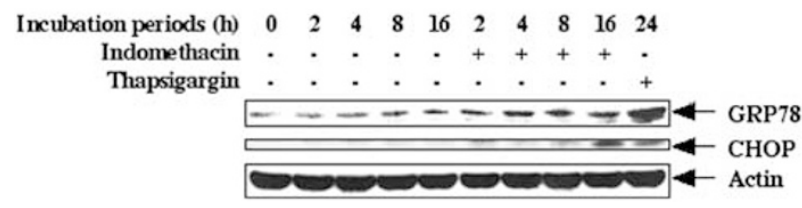

Figure 2 Immunoblotting analysis for induction of GRP78 and CHOP by indomethacin. Cultured gastric mucosal cells were incubated with $1 \mathrm{mM}$ indomethacin or $2 \mu \mathrm{M}$ thapsigargin (positive control) for the indicated periods. Whole cell extracts ( $20 \mu \mathrm{g}$ protein for GRP78, $5 \mu \mathrm{g}$ protein for actin and $30 \mu \mathrm{g}$ protein for CHOP) were analyzed by immunoblotting with an antibody against GRP78, actin or CHOP

increased the amount of GRP78 and CHOP mRNA, suggesting that these ER stress response-related proteins are induced at the level of transcription. Given that CHOP is a 


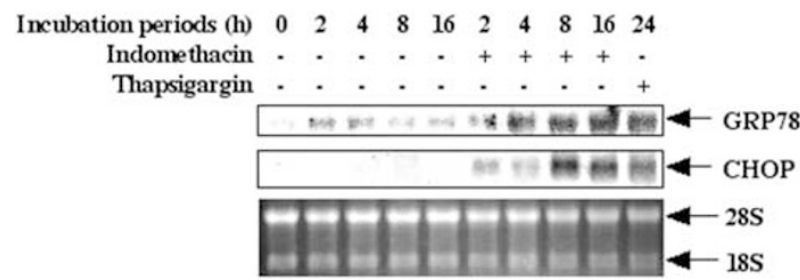

Figure 3 Northern blotting analysis for induction of GRP78 and CHOP mRNA by indomethacin. Cultured gastric mucosal cells were incubated with $1 \mathrm{mM}$ indomethacin or $2 \mu \mathrm{M}$ thapsigargin (positive control) for the indicated periods. The level of the GRP78 and CHOP mRNA was monitored by Northern blotting analysis. Bands of ribosomal RNA (28S and $18 \mathrm{~S}$ ) stained with ethidium bromide are shown

transcription factor involved in the induction of apoptosis, we then focused on CHOP induction by indomethacin in order to understand the mechanism of NSAID-induced apoptosis.

Induction of apoptosis is not specific for indomethacin, but is observed in response to NSAIDs in general. Given that we have previously found that aspirin, diclofenac, ibuprofen and celecoxib also induce apoptosis, ${ }^{9}$ we examined the effect of some of these agents on CHOP mRNA induction. As well as indomethacin $(1 \mathrm{mM})$, treatment of cells with diclofenac $(1 \mathrm{mM})$, ibuprofen $(2 \mathrm{mM})$ or celecoxib $(80 \mu \mathrm{M})$ caused a decrease in cell viability and apoptotic DNA fragmentation, confirming that apoptosis is induced under these conditions (Figure $4 \mathrm{a}$ and $\mathrm{b}$ ). These NSAIDs increased the amount of CHOP mRNA (Figure 4c). There are two subtypes of COX, these being COX-1 and COX-2, but COX activity in gastric mucosal cells is mainly derived from COX-1. With the exception of celecoxib, which is COX-2 specific, NSAIDs used in Figure 4 can inhibit both subtypes. ${ }^{20}$ Therefore, if the induction of $C H O P$ mRNA by indomethacin is caused by COX inhibition in gastric mucosal cells (in other words, inhibition of COX-1), higher concentrations of celecoxib would be required to reveal an effect. Given that the reverse was the case, it appears that CHOP induction by NSAIDs is not related to inhibition of COX and PG synthesis in gastric mucosal cells. Furthermore, we found that the addition of $\mathrm{PGE}_{2}$ to the culture medium did not attenuate apoptosis and CHOP induction by indomethacin (data not shown).

We have previously established conditions under which other gastric stressors (ethanol, hydrogen peroxide and hydrochloric acid) induce apoptosis in primary cultures of guinea-pig gastric mucosal cells. ${ }^{21}$ We therefore examined whether these gastric stressors induce CHOP under apoptotic conditions. Treatment of cells with $4 \%$ ethanol for $6 \mathrm{~h}, 300 \mu \mathrm{M}$ hydrogen peroxide for $6 \mathrm{~h}$ or $20 \mathrm{mM}$ hydrochloric acid for $8 \mathrm{~h}$ caused a decrease in cell viability and apoptotic DNA fragmentation (Figure $5 \mathrm{a}$ and $\mathrm{b}$ ). However, none of these gastric stressors induced $C H O P$ mRNA (Figure $5 \mathrm{c}$ ). Therefore, induction of CHOP (and possibly the ER stress response) is not generally observed for gastric stressor-induced apoptosis, but is specific for NSAID-induced apoptosis.

\section{Activation of ATF6 by indomethacin}

ER stress response element (ERSE) has been identified in the promoter of ER chaperons and $C H O P$ genes. $^{22} \mathrm{ER}$ trans-

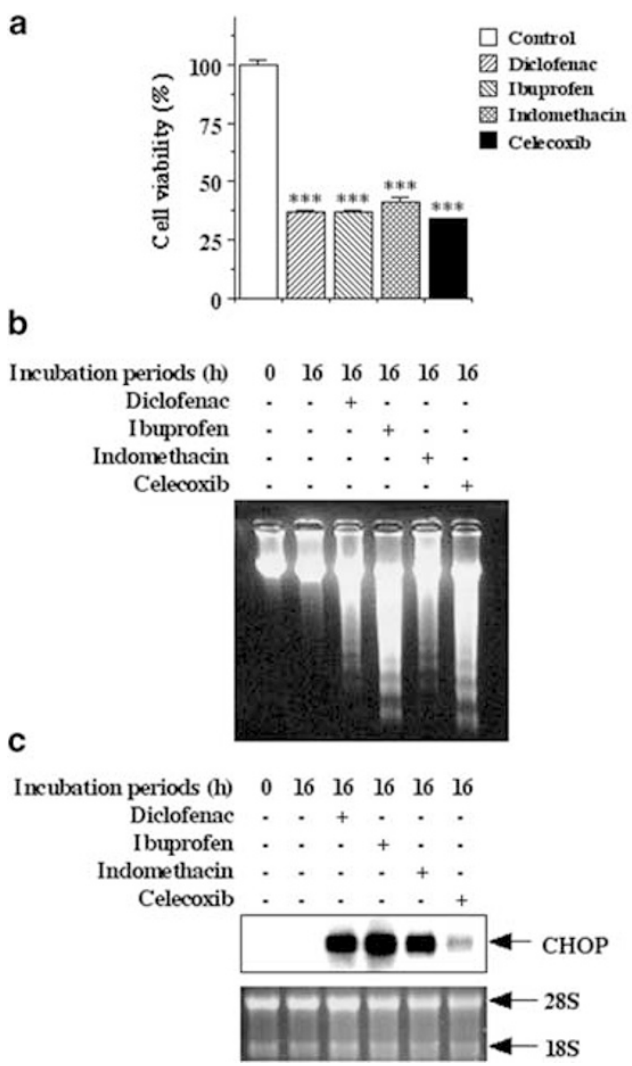

Figure 4 Induction of $C H O P$ mRNA by NSAIDs other than indomethacin. Cultured gastric mucosal cells were incubated with $1 \mathrm{mM}$ diclofenac, $2 \mathrm{mM}$ ibuprofen, $1 \mathrm{mM}$ indomethacin or $80 \mu \mathrm{M}$ celecoxib for $16 \mathrm{~h}$. Cell viability was determined by the MTT method. Values are expressed as mean + S.E.M. $(n=4)$. ${ }^{\star * \star} P<0.001$ (a). Chromosomal DNA was extracted and analyzed by $2 \%$ agarose gel electrophoresis (b). The level of CHOP mRNA was monitored by Northern blotting analysis. Bands of ribosomal RNA (28S and 18S) stained with ethidium bromide are shown (c)

membrane-localized p90-ATF6 (the inactive form of ATF6 for ERSE-dependent transcription) is cleaved into p50-ATF6, which translocates to the nucleus where it specifically binds to ERSE to activate the transcription from ERSE. ${ }^{13}$ The induction of GRP78 and CHOP mRNA by indomethacin (Figure 3) suggests that p90-ATF6 is activated (cleaved) into p50-ATF6. Immunoblotting analysis was used to confirm this point. Immunoblotting of whole cell extracts revealed that the p90-ATF 6 band disappeared following treatment of cells with indomethacin, as well as with thapsigargin (Figure 6a). Unfortunately, due to the presence of cross-reaction bands around p50-ATF6, we could not detect p50-ATF6 in whole cell extracts (data not shown). We therefore prepared nuclear extracts in which p50-ATF6 should be enriched. As shown in Figure $6 \mathrm{~b}$, the p50-ATF6 band was indeed detected in extracts prepared from indomethacin- or thapsigargin-treated cells, but not from control cells. As expected, the p90-ATF6 band was not detected in any nuclear extracts (data not shown). These results suggest that ATF6 is activated in the presence of indomethacin.

For further confirmation of this point, the transcriptional activity of ATF6 was measured using a reporter plasmid where the ERSE of the CHOP gene was inserted. ${ }^{23}$ 


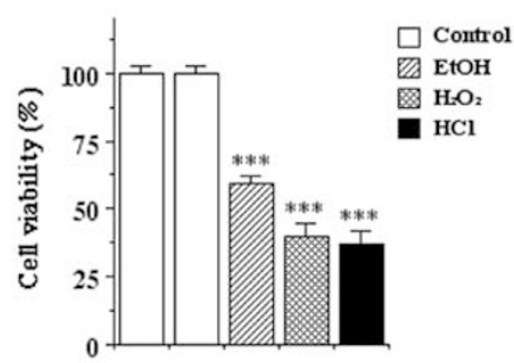

$\begin{array}{llllll}\text { Incubation periods (h) } & 6 & 8 & 6 & 6 & 8\end{array}$

b

Incubation periods (h) $\quad \begin{array}{lllllll}0 & 6 & 8 & 6 & 6 & 8\end{array}$

$\begin{array}{rllllll}\mathrm{EtOH} & - & \cdot & \cdot & + & - & \cdot \\ \mathrm{H}_{2} \mathrm{O}_{2} & - & \cdot & \cdot & \cdot & + & \end{array}$

$\mathrm{HCl} \cdot .+.++$

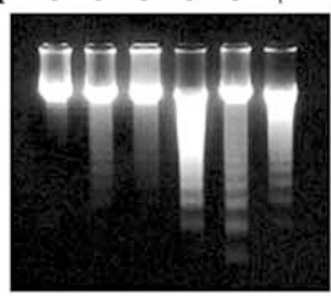

c

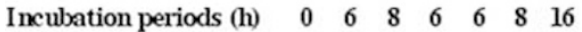

$\mathrm{EtOH} \cdot \cdot \cdot+\cdot \cdot \cdot$

$\mathrm{H}_{2} \mathrm{O}_{2} \cdot+\cdot++\cdot \cdot$

$\mathrm{HCl} \cdot+\cdot \cdot++\cdot$

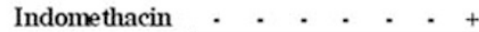

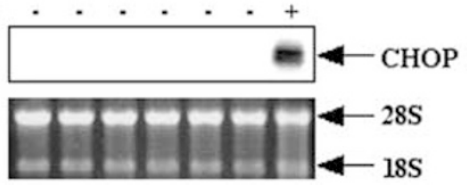

Figure 5 Induction of $\mathrm{CHOP}$ mRNA by gastric stressors other than NSAIDs. Cultured gastric mucosal cells were incubated with $4 \%$ ethanol $(\mathrm{EtOH})$ for $6 \mathrm{~h}$, $300 \mu \mathrm{M}$ hydrogen peroxide $\left(\mathrm{H}_{2} \mathrm{O}_{2}\right)$ for $6 \mathrm{~h}, 20 \mathrm{mM}$ hydrochloric acid $(\mathrm{HCl})$ for $8 \mathrm{~h}$ or $1 \mathrm{mM}$ indomethacin for $16 \mathrm{~h}$. Cell viability was determined by the MTT method. Values are mean \pm S.E.M. $(n=4)$. ${ }^{\star \star \star} P<0.001$ (a). Chromosomal DNA was extracted and analyzed by $2 \%$ agarose gel electrophoresis (b). The level of CHOP mRNA was monitored by Northern blotting analysis. Bands of ribosomal RNA (28S and $18 \mathrm{~S}$ ) stained with ethidium bromide are shown (c)

a \begin{tabular}{rllll} 
Incubation periods (h) & 0 & 16 & 16 & 24 \\
Indomethacin & $\cdot$ & $\cdot$ & + & $\cdot$ \\
Thapsigargin & $\cdot$ & $\cdot$ & $\cdot$ & + \\
\hline & - & - & - p90-ATF6
\end{tabular}

b \begin{tabular}{rllll} 
Incubation periods (h) & 0 & 16 & 16 & 24 \\
Indomethacin & $\cdot$ & $\cdot$ & + & $\cdot$ \\
Thapsigargin & $\cdot$ & $\cdot$ & $\cdot$ & + \\
\hline & $-\mathrm{p}$ & - & - & - Lamin B
\end{tabular}

Figure 6 Activation of ATF6 by indomethacin. Cultured gastric mucosal cells were incubated with $1 \mathrm{mM}$ indomethacin for $16 \mathrm{~h}$ or $2 \mu \mathrm{M}$ thapsigargin for $24 \mathrm{~h}$ (positive control). Whole cell extracts (100 $\mu \mathrm{g}$ protein for ATF6 and $5 \mu \mathrm{g}$ protein for actin) (a) or nuclear extracts (30 $\mu$ g protein for ATF6 and $5 \mu \mathrm{g}$ protein for lamin B) (b) were analyzed by immunoblotting with an antibody against ATF6, actin or lamin B
Compared with control cells (without ERSE in the promoter), treatment with indomethacin stimulated luciferase activity to a similar extent to that observed with thapsigargin in cells that have ERSE in the reporter plasmid (Figure 7). The stimulation of luciferase activity by thapsigargin was much the same as that previously reported. ${ }^{23}$ The results illustrated in Figures 6 and 7 suggest that ATF6 is activated in the presence of indomethacin, which in turn induces the transcription of the CHOP gene from ERSE.

We also measured the transcriptional activity of $\mathrm{CHOP}$ using a reporter plasmid where the $\mathrm{CHOP}$ binding site of the Rous sarcoma virus long terminal repeat was inserted. ${ }^{23}$ Compared with control cells (without the $\mathrm{CHOP}$ binding site in the promoter), treatment with indomethacin stimulated luciferase activity to a similar extent to that seen with thapsigargin in cells that have the $\mathrm{CHOP}$ binding site in the reporter plasmid (Figure 7). Taken together, the results illustrated in Figures 2, 3 and 7 suggest that the induction of $\mathrm{CHOP}$ by indomethacin is involved in altering the transcription of $\mathrm{CHOP}$-regulated genes, including those genes involved in apoptosis.

\section{Induction of ATF4 and XBP-1 by indomethacin}

In addition to regulation by ATF6 through ERSE, expression of the $C H O P$ gene is positively regulated by other transcription factors, such as ATF4 and XBP-1. ${ }^{24}$ The induction of ATF4 is dependent on PERK/PEK, whereas XBP-1 is dependent on both ATF6 and IRE1. ${ }^{11,12}$ ATF4 has been shown to bind to the promoter of the CHOP gene (the upstream region of ERSE) and activate $C H O P$ transcription, ${ }^{25}$ while XBP-1 binds to ERSE. ${ }^{24}$ As shown in Figure 8a, both ATF4 and XBP-1 mRNA were increased in the presence of indomethacin, as well as thapsigargin. The induction of ATF4 mRNA suggests that PERK/PEK is activated in the presence of indomethacin.

\section{Activation of XBP-1 and JNK by indomethacin}

IRE1 play an important role in ER stressor-dependent apoptosis. IRE1 activates caspase-12, XBP-1 and apopto-

Relative L uciferase Activity (\%)

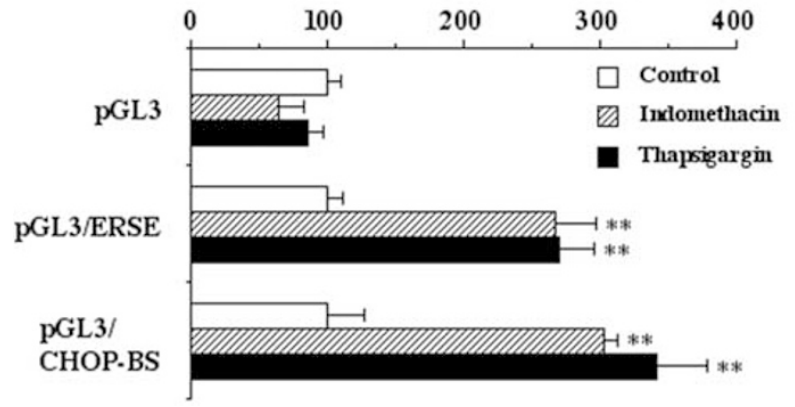

Figure 7 Activation by indomethacin of transcription from ERSE and the $\mathrm{CHOP}$ binding site. Cultured gastric mucosal cells were cotransfected with pRL-SV40 (internal control plasmid with the Renilla reniformis luciferase gene) and pGL3 (Photinus pyralis luciferase gene with SV40 promoter), pGL3/ERSE or pGL/ CHOP-BS. After $24 \mathrm{~h}$, cells were incubated with $1 \mathrm{mM}$ indomethacin or $2 \mu \mathrm{M}$ thapsigargin (positive control) for $8 \mathrm{~h}$. Fire fly luciferase activity was measured, normalized for Renilla reniformis luciferase activity, and expressed relative to the activity in the absence of these chemicals (control). Values are mean \pm S.E.M. $(n=3) .{ }^{*} P<0.01$ 
a

Incubation periods (h) $\quad 0 \quad 16 \quad 16 \quad 24$

Indomethacin : $\cdot+$

Thapsigargin * * + +

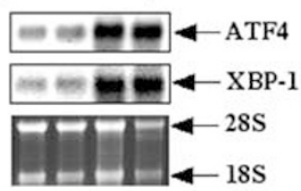

b

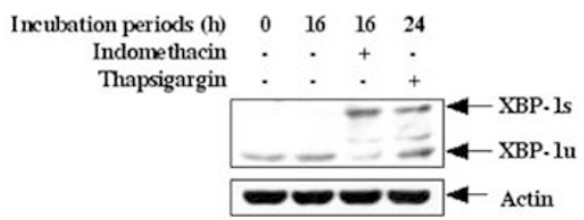

C

Incubation periock (min) $\quad \begin{array}{lllllllll}0 & 15 & 30 & 60 & 120 & 15 & 30 & 60 & 120\end{array}$ Indomethacin

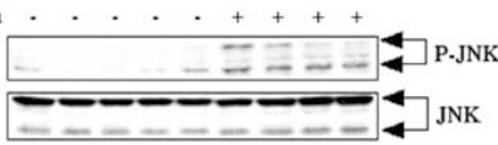

Figure 8 Induction and/or activation of ATF4, XBP-1 and JNK by indomethacin. Cultured gastric mucosal cells were incubated with $1 \mathrm{mM}$ indomethacin or $2 \mu \mathrm{M}$ thapsigargin (positive control) for indicated periods. The level of ATF4 or XBP-1 mRNA was monitored by Northern blotting analysis. Bands of ribosomal RNA (28S and 18S) stained with ethidium bromide are illustrated (a). Whole cell extracts ( $30 \mu \mathrm{g}$ protein for XBP-1, $5 \mu \mathrm{g}$ protein for actin and $20 \mu \mathrm{g}$ protein for JNK) were analyzed by immunoblotting with an antibody against XBP-1, JNK or phosphorylated JNK (P-JNK) (b, c). XBP-1s, spliced form of XBP-1; XBP-1u, unspliced form of XBP-1 (b)

sis-signal-regulating kinase 1 (ASK1), all of which are involved in apoptosis. ${ }^{26,27}$ We here examined the effect of NSAIDs on these IRE1-dependent pathway. Since antibody against mouse caspase-12 did not work for immunoblotting experiments of guinea-pig proteins, we could not reveal the effect of NSAIDs on caspase-12 activation.

IRE1 splices XBP-1 mRNA to converting it into a potent activator for transcription from ERSE. Both unspliced (inactive) and spliced (active) form of XBP-1 protein was observed in cells treated with indomethacin or thapsigargin, whereas only unspliced form of XBP-1 protein was observed in control cells (Figure $8 b$ ). This result suggests that IRE1 is activated in the presence of indomethacin.

ER stressors activate ASK1 through IRE1 and activated ASK1 induces apoptosis through activation (phosphorylation) of $\mathrm{c}$-Jun $\mathrm{NH}_{2}$-terminal kinase (JNK). As shown in Figure $8 \mathrm{c}$, phosphorylation of JNK was strongly induced by treatment of cells with indomethacin. Therefore, the ASK1 pathway seems to be activated by indomethacin.

\section{Involvement of CHOP in indomethacin-induced apoptosis}

In order to test whether the induction of CHOP by indomethacin is involved in indomethacin-induced apoptosis, we examined the effect of expression of the dominant-negative form of CHOP. Gastric mucosal cells were cotransfected with an enhanced green fluorescent protein (EGFP) expression plasmid and an expression plasmid for the dominant-negative form of CHOP prior to treatment with indomethacin (Figure 9).
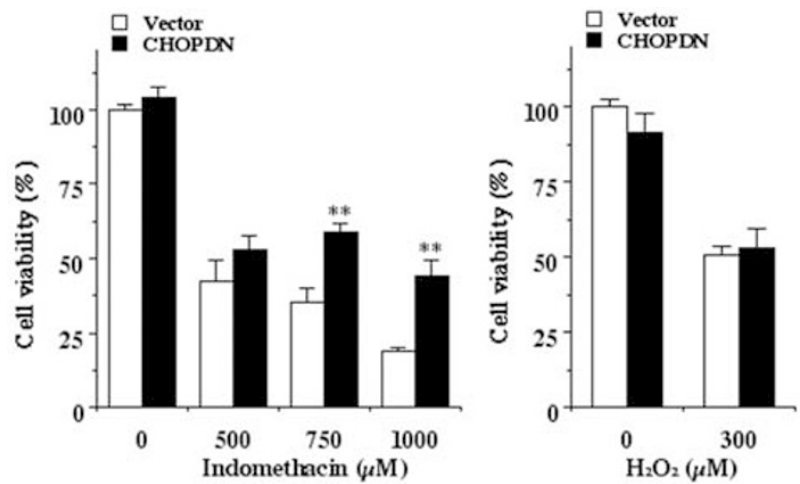

Figure 9 Prevention of indomethacin-induced apoptosis by the expression of the dominant-negative form of $\mathrm{CHOP}$. Cultured gastric mucosal cells were cotransfected with $3 \mu \mathrm{g}$ of pEGFP-C1 (EFGP expression plasmid) and $10 \mu \mathrm{g}$ of pOPRSVI-L133/L140ACHOP (expression plasmid for dominant-negative form of CHOP, CHOPDN) or vector. After $24 \mathrm{~h}$, the cells were incubated with the indicated concentrations of indomethacin for $12 \mathrm{~h}$ or with $300 \mu \mathrm{M}$ hydrogen peroxide $\left(\mathrm{H}_{2} \mathrm{O}_{2}\right)$ for $6 \mathrm{~h}$. Cells were observed by fluorescence microscope and EGFP-positive cells were counted and expressed relative to numbers of vectortransfected cells without stress. Values are expressed as mean \pm S.E.M. $(n=3)$. ${ }^{\star \star} P<0.01$

Since the transfection efficiency was not so high in primary culture of gastric mucosal cells, we measured the cell viability by counting EGFP-positive cells instead of MTT method, which was used in other experiments. The indomethacindependent decrease in cell viability was partially suppressed by expression of the dominant-negative form of $\mathrm{CHOP}$ (Figure 9). In contrast, expression of this form of CHOP did not alter the effect of hydrogen peroxide (Figure 9), which did not induce CHOP under the conditions (Figure 5). This result was consistent, even when higher concentrations of hydrogen peroxide were used (data not shown). Thus, the induction of CHOP appears to be involved in indomethacin-induced apoptosis.

For further confirming the involvement of $\mathrm{CHOP}$ in indomethacin-induced apoptosis, we used CHOP-deficient mice. Since primary culture of gastric mucosal cells has not been established in mouse, we used peritoneal macrophages. We previously reported that NO-induced apoptosis significantly decreased in peritoneal macrophages from CHOPdeficient mice. ${ }^{23}$ Peritoneal macrophages from wild-type mice or $\mathrm{CHOP}$-deficient mice were treated with indomethacin for $24 \mathrm{~h}$. As shown in Figure 10, indomethacin-induced chromatin condensation was observed in peritoneal macrophages from wild-type mice, but not so apparently in those from CHOPdeficient mice. This result also strongly suggests that the induction of CHOP is involved in indomethacin-induced apoptosis.

\section{Discussion}

In this study, we have demonstrated that NSAIDs activate the ER transmembrane protein ATF6 via its cleavage, and suggested that cleaved ATF6 stimulates the transcription of the CHOP gene from ERSE. That this CHOP induction is involved in NSAID-induced apoptosis was suggested by showing that expression of the dominant-negative form of CHOP partially suppresses the apoptosis induced by 
a

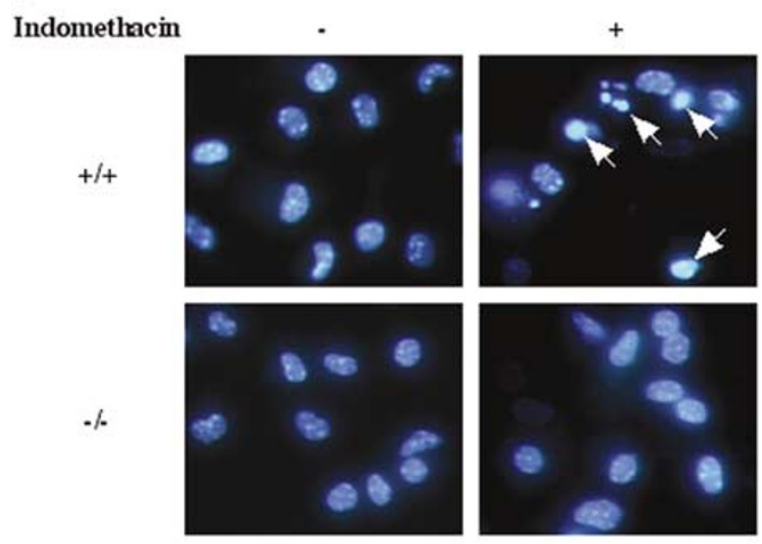

b

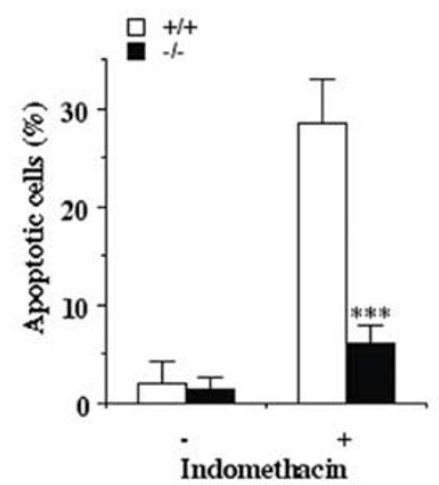

Figure 10 Peritoneal macrophages from $\mathrm{CHOP}$-deficient mice are resistant to indomethacin-induced apoptosis. Peritoneal macrophages from wild-type $(+1$ + ) or CHOP-deficient $(-/-)$ mice were treated with $1 \mathrm{mM}$ indomethacin for $24 \mathrm{~h}$. Cells were stained with Hoechst dye 33258 and observed under a fluorescence microscope. Arrows indicate condensed chromatins (a). Apoptotic cells with condensed chromatins were counted and expressed relative to total cells. Values are expressed as mean \pm S.E.M. $(n=3) .{ }^{\star \star \star} P<0.001$ (b)

indomethacin and that indomethacin-induced apoptosis was significantly inhibited in peritoneal macrophages from CHOPdeficient mice. We also showed that other factors, namely ATF4 and XBP-1, which positively regulate the CHOP transcription, are induced by NSAIDs, suggesting that not only ATF6 but also ATF4 and XBP-1 are involved in the induction of CHOP by NSAIDs. We consider that the concentrations of NSAIDs required for apoptosis in vitro are possible in vivo associating with gastric ulceration in animal models, as discussed in our previous paper. ${ }^{10}$

Suppression of NSAID-induced apoptosis by expression of the dominant-negative form of $\mathrm{CHOP}$ was only partial (Figure 9). Furthermore, expression of the wild-type CHOP did not induce apoptosis in the absence of stressors (data not shown). These data suggest that $\mathrm{CHOP}$-independent mechanisms are also involved in NSAID-induced apoptosis in gastric mucosal cells. ER stress activates ASK1 through IRE1 and tumor necrosis factor receptor-associated factor 2 (TRAF2) and activated ASK1 induces apoptosis through $\mathrm{JNK}^{28}$ On the other hand, caspase-12, an ER-associated caspase, may also be involved in NSAID-induced apoptosis. ER stress causes procaspase-12 to cluster at the ER membrane where it is activated via IRE1 and TRAF2. ${ }^{11}$
Activated caspase- 12 activates caspase- 9 and $-3 .{ }^{11}$ We here showed that JNK is activated in the presence of indomethacin and observation of spliced form of XBP-1 in cells treated with indomethacin suggested that IRE1 is activated under the conditions. Therefore, we consider that these CHOP-independent mechanisms are also involved in NSAID-induced apoptosis in gastric mucosal cells.

As described in Introduction, NSAID-induced apoptosis is involved in NSAID-induced gastric lesions in vivo. Therefore, results in this paper suggest that CHOP is involved in NSAIDinduced gastric lesions. We also showed that not only the apoptotic ER stress response but also the adaptive response (induction of GRP78) is induced by NSAIDs. Previously, many papers have reported that the expression of GRP78 in cells suppresses apoptosis. ${ }^{16,29}$ Therefore, induction of GRP78 by NSAIDs may be involved in protection of gastric mucosal cells from NSAID-induced apoptosis. We previously reported that geranylgeranylacetone, an inducer of cytosolic molecular chaperons (heat-shock proteins) and an antiulcer drug, protects gastric mucosal cells from apoptosis, resulting in suppression of gastric lesions. ${ }^{30}$ We propose that an inducer of ER molecular chaperons (such as GRP78) may become a new type of antiulcer drug. On the other hand, induction of GRP78 by NSAIDs may weaken the antitumor activities of NSAIDs through inhibiting NSAID-induced apoptosis in tumor cells. Since it was reported that GRP78 is overexpressed in some tumor cells, ${ }^{31}$ an inhibitor of GRP78 may have clinical benefit, because it may make tumor cells sensitive to NSAIDs.

Epidemiological studies have shown that prolonged use of aspirin or other NSAIDs reduces the risk of Alzheimer's disease. ${ }^{2}$ Treatment of amyloid precursor protein transgenic mice with some NSAIDs suppressed the development of amyloid plaques pathology ${ }^{32}$ and NSAIDs lowered the level of amyloid $\beta$-protein in cultured cells. ${ }^{5}$ Although it was recently reported that some NSAIDs inhibit $\gamma$-secretase that is involved in amyloid $\beta$-protein production, ${ }^{33}$ the mechanism for decrease in amyloid $\beta$-protein production by NSAIDs is not fully understood. We showed that induction of GRP78 and CHOP by indomethacin was not specifically observed in gastric mucosal cells but observed in other cells, such as HEK293 (human embryonic kidney) cells (data not shown). Since GRP78 was shown to decrease amyloid $\beta$-protein production, ${ }^{34}$ we propose that GRP78 induced by NSAIDs is involved in inhibition of amyloid $\beta$-protein production by NSAIDs and their anti-Alzheimer's disease activity.

\section{Materials and Methods}

\section{Chemicals, media and animals}

Fetal bovine serum (FBS) was obtained from Gibco. Indomethacin was purchased from Wako Co., while ibuprofen, diclofenac and 3-(4, 5dimethyl-thiazol-2-yl)-2, 5-diphenyl tetrazolium bromide (MTT) were from Sigma Co. Celecoxib was obtained from LKT Laboratories Inc. Pronase E and type I collagenase were purchased from Kaken Pharmaceutical Co. and Nitta Gelatin Co., respectively. An antibody against GRP78 was from StressGen Biotechnologies Corp. Antibodies against XBP-1, CHOP, actin, JNK and lamin B were from Santa Cruz Biotechnology Inc. An antibody against phosphorylated JNK was from Cell Signaling Corp. An antibody against ATF6 was kindly provided by Dr. K Mori (Kyoto University). 
Lipofectamine PLUS was obtained from Invitrogen Corp. The RNeasy kit was from Qiagen Co., the Rediprime II DNA Labeling system, $\left[\alpha{ }^{32} \mathrm{P}\right] \mathrm{dCTP}$ ( $3000 \mathrm{Ci} / \mathrm{mmol}$ ) from Amersham Pharmacia Biotech Co., and the Dual Luciferase Assay System from Promega Corp. Male guinea-pigs weighing 200-300 g were purchased from Shimizu Co. The experiments and procedures described here were approved by the Animal Care Committee of Okayama University.

\section{Plasmid}

A Photinus pyralis luciferase reporter (pGL3) and an internal standard plasmid harboring the Renilla reniformis luciferase gene ( $p R L-S V 40$ ) were obtained from Promega Corp. A plasmid in which the ERSE of the human $\mathrm{CHOP}$ gene or the CHOP binding site of the Rous sarcoma virus long terminal repeat was inserted (pGL3/ERSE or pGL3/CHOP-BS, respectively) was produced as described previously. ${ }^{23}$ The mammalian expression plasmid for the dominant-negative form of CHOP (pOPRSVI-L133/L140ACHOP) was as described elsewhere. ${ }^{13,23,35}$ A plasmid expressing EGFP (pEGFP-C1) was obtained from CLONTECH Laboratories Inc.

\section{Cell culture and transfection}

Gastric mucosal cells were isolated from guinea-pig fundic glands, as described previously. ${ }^{36}$ After treatment with type I collagenase $(80 \mu \mathrm{g} / \mathrm{ml})$ and Pronase $\mathrm{E}(1 \mathrm{mg} / \mathrm{ml})$, cells were washed with medium containing FBS to stop the reaction of these enzymes. Then, cells $\left(6 \times 10^{5}\right.$ cells/wells $)$ were cultured for 1 day in RPMI 1640 containing $0.3 \% \mathrm{v} / \mathrm{v} \mathrm{FBS,} 100 \mathrm{U} / \mathrm{ml}$ penicillin and $100 \mu \mathrm{g} / \mathrm{ml}$ streptomycin in type-I collagen-coated plastic culture plates (Iwaki) in $5 \% \mathrm{CO}_{2} / 95 \%$ air at $37^{\circ} \mathrm{C}$. After removing nonadherent cells by washing with RPMI 1640 , cells that were attached to the plate at about $50 \%$ confluence were used. Guinea-pig gastric mucosal cells prepared under these conditions have been previously characterized, with the majority (about $90 \%$ ) of such cells being identified as pit cells. ${ }^{36,37}$ Cells were exposed to gastric stressors by changing the entire bathing medium.

Peritoneal macrophages were prepared from wild-type or CHOPdeficient mice as described previously. ${ }^{23}$ Female mice were intraperitoneally given with $3 \mathrm{ml}$ of $10 \%$ polypeptone (Difco), and peritoneal cells were harvested after 3 days. Cells were cultured in RPMI1640 medium supplemented with $10 \%$ heat-inactivated FBS. After 2 days incubation, nonadherent cells were removed by three times washing with PBS and adherent cells were cultured in the presence or absence of indomethacin.

Transfection of cultured guinea-pig gastric mucosal cells with plasmids was carried out using Lipofectamine PLUS according to the manufacturer's protocols.

\section{Cell viability assay}

Cell viability was determined by the MTT method as described previously. ${ }^{10}$ After the treatment with NSAIDs or other gastric irritants, cells were incubated with MTT solution at the final concentration of $1 \mathrm{mg} /$ $\mathrm{ml}$ in PBS for $2 \mathrm{~h}$. Isopropanol and hydrochloric acid were added to the final concentrations of $50 \%$ and $20 \mathrm{mM}$, respectively. The optical density at $570 \mathrm{~nm}$ was determined by spectrophotometer using a reference wavelength of $630 \mathrm{~nm}$.

Apoptotic DNA fragmentation was monitored as previously described..$^{38}$ Cells were collected using a rubber policeman and suspended in $70 \mu \mathrm{l}$ of lysis buffer, consisting of $50 \mathrm{mM}$ Tris- $\mathrm{HCl}$ ( $\mathrm{pH} \mathrm{7.8),} 10 \mathrm{mM}$ EDTA, and $0.5 \%$ sodium- $\mathrm{N}$-lauroylsarcosinate. Proteinase $\mathrm{K}$ was added to a final concentration of $1 \mathrm{mg} / \mathrm{ml}$, and the lysate was incubated at $50^{\circ} \mathrm{C}$ for $2 \mathrm{~h}$. RNaseA was then added to a final concentration of $0.5 \mathrm{mg} / \mathrm{ml}$ and incubated at $50^{\circ} \mathrm{C}$ for $30 \mathrm{~min}$. These samples were analyzed by $2 \%$ agarose gel electrophoresis in the presence of $0.5 \mu \mathrm{g} / \mathrm{ml}$ ethidium bromide.

Apoptotic chromatin condensation was monitored as described previously. ${ }^{21}$ Cells were washed with PBS and fixed with $4 \% \mathrm{v} / \mathrm{v}$ formaldehyde for $1 \mathrm{~h}$. Cells were then washed with PBS, stained with $10 \mu \mathrm{g} / \mathrm{ml}$ Hoechst dye 33258 and observed under a fluorescence microscope.

\section{Immunoblotting and Northern blotting analyses}

Whole cell extracts were prepared as described previously, ${ }^{21}$ as were nuclear extracts. ${ }^{39}$ The protein concentration of the samples was determined by the Bradford method. Samples were applied to 8,10 or $12 \%$ polyacrylamide gels containing SDS, subjected to electrophoresis, and proteins were then immunoblotted with each antibody.

Total RNA was extracted from the cells using an RNeasy kit according to the manufacturer's protocols. Samples ( $5 \mu \mathrm{g}$ RNA) were separated by agarose $(1 \%)$ gel electrophoresis in the presence of $6.3 \%$ formaldehyde and blotted onto nylon membranes. DNA probes for GRP78, CHOP, ATF4 and XBP-1 were amplified by PCR as described ${ }^{23,40,41}$ and labeled using the Rediprime II DNA Labeling system according to the manufacturer's instructions. After hybridization and washing, membranes were analyzed with BAS2000A (FUJIX).

\section{Luciferase assay}

Cells were transfected with $2 \mu \mathrm{g}$ of each of the Photinus pyralis luciferase reporter plasmids (pGL3 and its derivatives) and $0.4 \mu \mathrm{g}$. of internal standard plasmid bearing the Renilla reniformis luciferase reporter ( $\mathrm{pRL}$ SV40). Photinus pyralis luciferase activity in cell extracts was measured using the Dual Luciferase Assay System and then normalized for Renilla reniformis luciferase activity.

\section{Statistical analysis}

All values are expressed as the mean \pm standard error (S.E. M.). One-way analysis of variance (ANOVA) followed by Scheffe's multiple comparison was used for evaluation of differences between the groups. A Student's $t$ test for unpaired results was performed to test differences between two groups. Results were considered to be significant for values of $P<0.05$.

\section{Acknowledgements}

This work was supported by Grants-in-Aid for Scientific Research from the Ministry of Health, Labour, and Welfare of Japan. We thank Dr. K Mori (Kyoto University) and S Akira (Osaka University) for the antibody against ATF6 and the expression plasmid for the dominant-negative form of $\mathrm{CHOP}$, respectively.

\section{References}

1. Smalley WE, Ray WA, Daugherty JR and Griffin MR (1995) Nonsteroidal antiinflammatory drugs and the incidence of hospitalizations for peptic ulcer disease in elderly persons. Am. J. Epidemiol. 141: 539-545

2. Akiyama H, Barger $S$, Barnum S, Bradt B, Bauer J, Cole GM, Cooper NR, Eikelenboom P, Emmerling M, Fiebich BL, Finch CE, Frautschy S, Griffin WS, 
Hampel H, Hull M, Landreth G, Lue L, Mrak R, Mackenzie IR, McGeer PL, O'Banion MK, Pachter J, Pasinetti G, Plata-Salaman C, Rogers J, Rydel R, Shen Y, Streit W, Strohmeyer R, Tooyoma I, Van Muiswinkel FL, Veerhuis R, Walker D, Webster S, Wegrzyniak B, Wenk G and Wyss-Coray T (2000) Inflammation and Alzheimer's disease. Neurobiol. Aging 21: 383-421

3. Levy GN (1997) Prostaglandin H synthases, nonsteroidal anti-inflammatory drugs, and colon cancer. FASEB J. 11: 234-247

4. Rogers J, Webster S, Lue LF, Brachova L, Civin WH, Emmerling M, Shivers B, Walker D and McGeer P (1996) Inflammation and Alzheimer's disease pathogenesis. Neurobiol. Aging 17: 681-686

5. Weggen S, Eriksen JL, Das P, Sagi SA, Wang R, Pietrzik CU, Findlay KA, Smith TE, Murphy MP, Bulter T, Kang DE, Marquez-Sterling N, Golde TE and Koo EH (2001) A subset of NSAIDs lower amyloidogenic Abeta42 independently of cyclooxygenase activity. Nature 414: 212-216

6. Rigas B and Shiff SJ (2000) Is inhibition of cyclooxygenase required for the chemopreventive effect of NSAIDs in colon cancer. A model reconciling the current contradiction. Med. Hypotheses 54: 210-215

7. Hawkey CJ (2000) Nonsteroidal anti-inflammatory drug gastropathy. Gastroenterology 119: 521-535

8. Singh G (1998) Recent considerations in nonsteroidal anti-inflammatory drug gastropathy. Am. J. Med. 105: 31S-38S

9. Tomisato W, Tsutsumi S, Hoshino T, Hwang HJ, Mio M, Tsuchiya T and Mizushima T (2004) Role of direct cytotoxic effects of NSAIDs in the induction of gastric lesions. Biochem. Pharmacol. 67: 575-585

10. Tomisato W, Tsutsumi S, Rokutan K, Tsuchiya T and Mizushima T (2001) NSAIDs induce both necrosis and apoptosis in guinea pig gastric mucosal cells in primary culture. Am. J. Physiol. Gastrointest. Liver Physiol. 281: G1092G1100

11. Kaufman RJ (2002) Orchestrating the unfolded protein response in health and disease. J. Clin. Invest. 110: 1389-1398

12. Ron D (2002) Translational control in the endoplasmic reticulum stress response. J. Clin. Invest. 110: 1383-1388

13. Yoshida H, Okada T, Haze K, Yanagi H, Yura T, Negishi M and Mori K (2000) ATF6 activated by proteolysis binds in the presence of NF-Y (CBF) directly to the cis-acting element responsible for the mammalian unfolded protein response. Mol. Cell. Biol. 20: 6755-6767

14. Kaufman RJ (1999) Stress signaling from the lumen of the endoplasmic reticulum: coordination of gene transcriptional and translational controls. Genes Dev 13: 1211-1233

15. Mori K (2000) Tripartite management of unfolded proteins in the endoplasmic reticulum. Cell 101: 451-454

16. Liu H, Bowes III RC, van de Water B, Sillence C, Nagelkerke JF and Stevens JL (1997) Endoplasmic reticulum chaperones GRP78 and calreticulin prevent oxidative stress, $\mathrm{Ca}^{2+}$ disturbances, and cell death in renal epithelial cells. J. Biol. Chem. 272: 21751-21759

17. Reddy RK, Lu J and Lee AS (1999) The endoplasmic reticulum chaperone glycoprotein GRP94 with $\mathrm{Ca}(2+)$-binding and antiapoptotic properties is a novel proteolytic target of calpain during etoposide-induced apoptosis. J. Biol. Chem. 274: 28476-28483

18. Zinszner H, Kuroda M, Wang $X$, Batchvarova N, Lightfoot RT, Remotti $H$, Stevens JL and Ron D (1998) CHOP is implicated in programmed cell death in response to impaired function of the endoplasmic reticulum. Genes Dev. 12: 982-995

19. Mengesdorf T, Althausen S, Oberndorfer I and Paschen W (2001) Response of neurons to an irreversible inhibition of endoplasmic reticulum $\mathrm{Ca}(2+)$-ATPase: relationship between global protein synthesis and expression and translation of individual genes. Biochem. J. 356 (Part 3): 805-812

20. Kawai $S$, Nishida $S$, Kato M, Furumaya $Y$, Okamoto $R$, Koshino $T$ and Mizushima $Y$ (1998) Comparison of cyclooxygenase-1 and -2 inhibitory activities of various nonsteroidal anti-inflammatory drugs using human platelets and synovial cells. Eur. J. Pharmacol. 347: 87-94

21. Tsutsumi S, Tomisato W, Takano T, Rokutan K, Tsuchiya T and Mizushima T (2002) Gastric irritant-induced apoptosis in guinea pig gastric mucosal cells in primary culture. Biochim. Biophys. Acta 1589: 168-180

22. Yoshida H, Haze K, Yanagi H, Yura T and Mori K (1998) Identification of the cisacting endoplasmic reticulum stress response element responsible for transcriptional induction of mammalian glucose-regulated proteins. Involvement of basic leucine zipper transcription factors. J. Biol. Chem. 273 33741-33749

23. Gotoh T, Oyadomari S, Mori K and Mori M (2002) Nitric oxide-induced apoptosis in RAW 264.7 macrophages is mediated by endoplasmic reticulum stress pathway involving ATF6 and CHOP. J. Biol. Chem. 277: 12343-12350

24. Yoshida H, Matsui T, Yamamoto A, Okada T and Mori K (2001) XBP1 mRNA is induced by ATF6 and spliced by IRE1 in response to ER stress to produce a highly active transcription factor. Cell 107: 881-891

25. Ma Y, Brewer JW, Diehl JA and Hendershot LM (2002) Two distinct stress signaling pathways converge upon the $\mathrm{CHOP}$ promoter during the mammalian unfolded protein response. J. Mol. Biol. 318: 1351-1365

26. Yoneda T, Imaizumi K, Oono K, Yui D, Gomi F, Katayama T and Tohyama M (2001) Activation of caspase-12, an endoplasmic reticulum (ER) resident caspase, through tumor necrosis factor receptor-associated factor 2-dependent mechanism in response to the ER stress. J. Biol. Chem. 276: $13935-13940$

27. Lee K, Tirasophon W, Shen X, Michalak M, Prywes R, Okada T, Yoshida H, Mori K and Kaufman RJ (2002) IRE1-mediated unconventional mRNA splicing and S2P-mediated ATF6 cleavage merge to regulate XBP1 in signaling the unfolded protein response. Genes Dev. 16: 452-466

28. Nishitoh H, Matsuzawa A, Tobiume K, Saegusa K, Takeda K, Inoue K, Hori S, Kakizuka A and Ichijo H (2002) ASK1 is essential for endoplasmic reticulum stress-induced neuronal cell death triggered by expanded polyglutamine repeats. Genes Dev. 16: 1345-1355

29. Sugawara S, Takeda K, Lee A and Dennert G (1993) Suppression of stress protein GRP78 induction in tumor B/C10ME eliminates resistance to cell mediated cytotoxicity. Cancer Res. 53: 6001-6005

30. Takano T, Tsutsumi S, Tomisato W, Hoshino T, Tsuchiya T and Mizushima T (2002) Geranylgeranylacetone protects guinea pig gastric mucosal cells from gastric stressor-induced apoptosis. Dig. Dis. Sci. 47: 1546-1553

31. Fernandez PM, Tabbara SO, Jacobs LK, Manning FC, Tsangaris TN, Schwartz AM, Kennedy KA and Patierno SR (2000) Overexpression of the glucoseregulated stress gene GRP78 in malignant but not benign human breast lesions. Breast Cancer Res. Treat. 59: 15-26

32. Lim GP, Yang F, Chu T, Chen P, Beech W, Teter B, Tran T, Ubeda O, Ashe $\mathrm{KH}$, Frautschy SA and Cole GM (2000) Ibuprofen suppresses plaque pathology and inflammation in a mouse model for Alzheimer's disease. J. Neurosci. 20: 5709-5714

33. Takahashi $\mathrm{Y}$, Hayashi I, Tominari $\mathrm{Y}$, Rikimaru K, Morohashi $\mathrm{Y}$, Kan $\mathrm{T}$, Natsugari H, Fukuyama T, Tomita T and Iwatsubo T (2003) Sulindac sulfide is a noncompetitive gamma-secretase inhibitor that preferentially reduces Abeta 42 generation. J. Biol. Chem. 278: 18664-18670

34. Yang Y, Turner RS and Gaut JR (1998) The chaperone BiP/GRP78 binds to amyloid precursor protein and decreases Abeta40 and Abeta42 secretion. J. Biol. Chem. 273: 25552-25555

35. Matsumoto M, Minami M, Takeda K, Sakao Y and Akira S (1996) Ectopic expression of CHOP (GADD153) induces apoptosis in M1 myeloblastic leukemia cells. FEBS Lett. 395: 143-147

36. Hirakawa T, Rokutan K, Nikawa T and Kishi K (1996) Geranylgeranylacetone induces heat shock proteins in cultured guinea pig gastric mucosal cells and rat gastric mucosa. Gastroenterology 111: 345-357

37. Tomisato W, Hoshino T, Tsutsumi S, Tsuchiya T and Mizushima T (2002) Maturation-associated increase in sensitivity of cultured guinea pig gastric pit cells to hydrogen peroxide. Dig. Dis. Sci. 47: 2125-2133

38. Hoshino T, Tsutsumi S, Tomisato W, Hwang HJ, Tsuchiya T and Mizushima T (2003) Prostaglandin E2 protects gastric mucosal cells from apoptosis via EP2 and EP4 receptor activation. J. Biol. Chem. 278: 12752-12758

39. Schreiber E, Matthias P, Muller MM and Schaffner W (1989) Rapid detection of octamer binding proteins with 'mini-extracts', prepared from a small number of cells. Nucleic Acids Res. 17: 6419

40. Haas IG and Meo T (1988) cDNA cloning of the immunoglobulin heavy chain binding protein. Proc. Natl. Acad. Sci. USA 85: 2250-2254

41. Carninci P and Hayashizaki Y (1999) High-efficiency full-length cDNA cloning. Methods Enzymol. 303: 19-44 